4. Na SJ, Chung CR, Jeon K, Park CM, Suh GY, Ahn JH, Carriere KC, Song YB, Choi JO, Hahn JY, Choi JH, Choi SH, On YK, Gwon HC, Jeon ES, Kim DK, Yang JH. Association Between Presence of a Cardiac Intensivist and Mortality in an Adult Cardiac Care Unit. J Am Coll Cardiol 2016;68:2637-2648.

5. Shaefi S, O'Gara B, Kociol RD, Joynt K, Mueller A, Nizamuddin J, Mahmood E, Talmor D, Shahul S. Effect of cardiogenic shock hospital volume on mortality in patients with cardiogenic shock. J Am Heart Assoc 2015;4:e001462.

\section{A LIFE SUPPORT-BASED COMPREHENSIVE TREATMENT REGIMEN DRAMATICALLY REDUCED IN-HOSPITAL MORTALITY OF FULMINANT MYOCARDITIS PATIENTS}

Dao Wen Wang, Jiangang Jiang, Sheng Li, Yan Wang, Hong Wang, Houjuan Zuo, Ning Zhou, The Chinese Society of Cardiology. Department of Internal Medicine and Institute of Hypertension, Tongji Hospital, Tongji Medical College, Huazhong University of Science and Technology, Wuhan, China

10.1136/heartasia-2019-apahff.14

Fulminant myocarditis is chiefly caused by viral infections. Its onset is rapid, progresses quickly, and may lead to severe heart failure, circulatory failure and cardiogenic shock in a short time. Its mortality can be up to 50\%-70\%. Most importantly, there are no treatment options, and no evidence-based international guidelines or expert consensus statements. Here we provide the first expert consensus the Chinese Society of Cardiology Expert Consensus Statement on the Diagnosis and Treatment of Fulminant Myocarditis - based on data from our recent registered clinical trial. In this statement, we describe for the first time its clinical features and diagnostic criteria, and importantly, a new treatment regimen, 'life support-based comprehensive treatment regimen'. This comprehensive treatment regimen includes meticulous nutritional and fluid management, administration of glucocorticoid, immunoglobulin and antiviral agents, continuous renal replacement therapy, life-support treatments including application of mechanical respirator(s) and circulatory support systems, intraaortic balloon pulsation (IABP) and extracorporeal membrane oxygenation (ECMO) as well as cardiac pacing if needed. Our practice in multiple cardiac centres demonstrated effectiveness of this treatment by dramatically lowering the mortality of patients with fulminant myocarditis.

\section{IMPELLA ${ }^{\circledR}$ USE IN PROTECTED PCI AND CARDIOGENIC SHOCK}

Chui Ka Lung. Division of Cardiology, Department of Medicine and Therapeutics, Prince of Wales Hospital, Shatin, Hong Kong SAR

\subsection{6/heartasia-2019-apahff.15}

Intra-aortic balloon pump (IABP) has been used for many years in high-risk PCI or cardiogenic shock. However, the support provided by IABP is limited and a major randomised controlled trial failed to demonstrate a beneficial effect. ${ }^{1}$ Impella ${ }^{\circledR}$ is a family of percutaneous mechanical circulatory support (MCS) devices that are used in protected PCI and cardiogenic shock. ${ }^{2}$ Depending on the device model, they provide a blood flow ranging from 2.5 to $5 \mathrm{~L} / \mathrm{min}$. The resulting augmented support increases mean arterial blood pressure, cardiac output and coronary flow while unloading left ventricular filling pressure to reduce myocardial oxygen demand. ${ }^{2}{ }^{3}$ This is an ideal form of temporary support device for the patient. Moreover, the device is easy to set up and can be inserted very quickly to stabilise the patient. This presentation provides a review on the current data regarding the use of Impella MCS devices.

\section{REFERENCES}

1. Thiele H, Zeymer U, Neumann FJ, Ferenc M, Olbrich HG, Hausleiter J, Richardt G, Hennersdorf M, Empen K, Fuernau G, Desch S, Eitel I, Hambrecht R, Fuhrmann J, Böhm M, Ebelt H, Schneider S, Schuler G, Werdan K; IABP-SHOCK II Trial Investigators. Intraaortic balloon support for myocardial infarction with cardiogenic shock. N Engl J Med 2012;367:1287-1296.

2. O'Neill WW, Kleiman NS, Moses J, Henriques JP, Dixon S, Massaro J, Palacios I, Maini B, Mulukutla S, Dzavík V, Popma J, Douglas PS, Ohman M. A prospective, randomized clinical trial of hemodynamic support with Impella 2.5 versus intraaortic balloon pump in patients undergoing high-risk percutaneous coronary intervention: the PROTECT II study. Circulation 2012;126:1717-1727.

3. O'Neill WW, Grines C, Schreiber T, Moses J, Maini B, Dixon SR, Ohman EM Analysis of outcomes for 15,259 US patients with acute myocardial infarction cardiogenic shock (AMICS) supported with the Impella device. Am Heart $J$ 2018:202:33-38.

\section{ECMO AND MCS FOR PATIENTS UNDERGOING PCI: EXPERIENCE FROM TAIPEI VETERANS GENERAL HOSPITAL}

Wei-Ting Wang. Cardiology Division, Taipei Veterans General Hospital, Taipei, Taiwan ROC

\subsection{6/heartasia-2019-apahff.16}

Intra-aortic balloon pump (IABP), which simultaneously augments coronary blood flow and decreases myocardial oxygen demand, usually provides haemodynamic support in patients with impaired left ventricular function undergoing percutaneous coronary intervention $(\mathrm{PCI})^{1}{ }^{2}$ or for patients with established cardiogenic shock. ${ }^{3}$

Several observational studies have reported that prophylactic IABP insertion could reduce major adverse cardiovascular events (MACE) compared with a provisional counterpulsation strategy during high-risk PCI. ${ }^{4}$ However, meta-analysis did not reveal a benefit of routine elective use of IABP or percutaneous ventricular assisted device. ${ }^{5}$ Due to a lack of national data from Taiwan, this presentation therefore summarises the experience at Taipei Veterans General Hospital, and the patients' clinical characteristics and longterm outcomes including cardiac mortality and MACE associated with high-risk PCI and/or acute myocardial infarction.

\section{REFERENCES}

1. Kern MJ, Aguirre F, Bach R, Donohue T, Siegel R, Segal J. Augmentation of coronary blood flow by intra-aortic balloon pumping in patients after coronary angioplasty. Circulation 1993;87:500-511.

2. Cohen M, Urban P, Christenson JT, Joseph DL, Freedman RJ Jr, Miller MF, Ohman EM, Reddy RC, Stone GW, Ferguson JJ 3rd; Benchmark Registry Collaborators. Intra-aortic balloon counterpulsation in US and non-US centres: results of the Benchmark Registry. Eur Heart J 2003;24:1763-1770.

3. Sjauw KD, Engstrom $A E$, Vis MM, van der Schaaf RJ, Baan J Jr, Koch KT, de Winter RJ, Piek JJ, Tijssen JG, Henriques JP. A systematic review and meta-analysis of intra-aortic balloon pump therapy in ST-elevation myocardial infarction: should we change the guidelines? Eur Heart J 2009;30:459-468.

4. Mishra S, Chu WW, Torguson R, Wolfram R, Deible R, Suddath WO, Pichard AD, Satler LF, Kent KM, Waksman R. Role of prophylactic intra-aortic balloon pump in high-risk patients undergoing percutaneous coronary intervention. Am J Cardiol 2006;98:608-612.

5. Lee JM, Park J, Kang J, Jeon KH, Jung JH, Lee SE, Han JK, Kim HL, Yang HM, Park KW, Kang HJ, Koo BK, Kim SH, Kim HS. The efficacy and safety of mechanical hemodynamic support in patients undergoing high-risk percutaneous coronary intervention with or without cardiogenic shock: Bayesian approach network metaanalysis of 13 randomized controlled trials. Int J Cardiol 2015;184:36-46. 